\title{
Mercantilist Dualization: \\ The Introduction of the Euro, Redistribution of Industry Rents, and Wage Inequality in Germany, 1993-2008.
}

\author{
Fabian Ochsenfeld \\ Goethe University \\ Frankfurt am Main
}

Working Paper

published as:

Ochsenfeld, F.: Mercantilist dualization: the introduction of the euro, redistribution of industry rents, and wage inequality in Germany, 1993-2008.

Socio-Economic Review: doi:10.1093/ser/mwx026

Funding: This work was funded by Priority Program 1764 of the German Science Foundation (DFG), project GA 758/4-1 Organizational Structure, Technological Change and Rising Wage Inequality in Germany: An Empirical Study Using Linked-Employer-Employee Data and LOEWE Center Sustainable Architecture for Finance in Europe.

Acknowledgements: Earlier versions of this article were presented at research seminars at the University of Berne, Karlsruhe Institute of Technology, Venice International University, the $3^{\text {rd }}$ Network Meeting of the DFG priority program 1764, the 2015 BIGSSS Conference, the 2015 Summer School on Labor Market Research at ZEW Mannheim, and the 2016 ECSRConference in Oxford. I thank all participants at those presentations as well as Jan Brülle, Markus Gangl, Carlotta Giustozzi, Pilar Gonalons-Pons, Anne Kronberg, Timo Lepper, Kristina Lindemann, Daniel Mertens, Andreas Nölke for helpful comments. The data basis for this article is SIAB-R 7510 and LIAB QM2 9319, the Linked Employer-Employee Data of the IAB. Data were accessed during research stays at the Research Data Centre of the Federal Employment Agency's Institute for Employment Research (FDZ) and through a job submission application controlled by the FDZ. I thank the employees at the FDZ for their support.

Keywords: Income distribution, manufacturing, causal mechanisms, political economy, Germany, Europe.

JEL classification: E65, J31, N64. 


\title{
Mercantilist Dualization: \\ The Introduction of the Euro, Redistribution of Industry Rents, and Wage Inequality in Germany, 1993-2008.
}

\begin{abstract}
The current debate over distributional implications of the crisis-ridden Economic and Monetary Union (EMU) is heavily biased towards international accounts. Little attention is paid to who wins and who loses out intranationally. I argue that in Germany the EMU has reinforced dualization, the insider-outsider cleavage in the country's welfare state and production model. To scrutinize this argument, I analyze longitudinal linked employeremployee data ( $\mathrm{N}>9.6 \mathrm{mio}$ ) and pursue a mechanistic three-step identification strategy: First, I illustrate how the introduction of the Euro distorted real interest and exchange rates within the Eurozone. Second, I demonstrate how these imbalances redistributed rents from the domestic sector, in particular from construction, to the core manufacturing industry. Third, I show how this shift in industry rents reverberated to the wage distribution and increased inequality. The study contributes to resolve the puzzle why wage inequality in Germany increased through a fanning out of the wage distribution whereas countries similarly exposed to technological change and globalization grew unequal through a polarization of their wage distribution.
\end{abstract}




\section{Introduction}

Over the past three decades, wage inequality in Germany has increased significantly, following the trend of most OECD countries (Dustmann et al., 2009, Card et al., 2013). The general surge in wage inequality has given rise to theory and evidence that this is due to two developments all industrialized countries are exposed to: the integration of countries into globalized trade (Feenstra and Hanson, 1999), and the IT-enabled automatization of routine manufacturing and white collar work (Autor, 2015). Although these explanations are supported by strong empirical evidence, the patterns by which inequality has grown differ markedly between countries. Whereas median U.S. wages have converged towards wages paid to workers located in the bottom part of the distribution since the early 1990s (Autor et al., 2008), Germany's wage structure has been 'fanning out' since the mid-1990s, in the sense that inequality has increased between the middle and the top and also between the bottom and the middle (Figure 1; Dustmann et al., 2009).

Figure 1. Indexed $(\log )$ real wage growth at the $20^{\text {th }}, 50^{\text {th }}$, and $80^{\text {th }}$ percentile. 19932008.

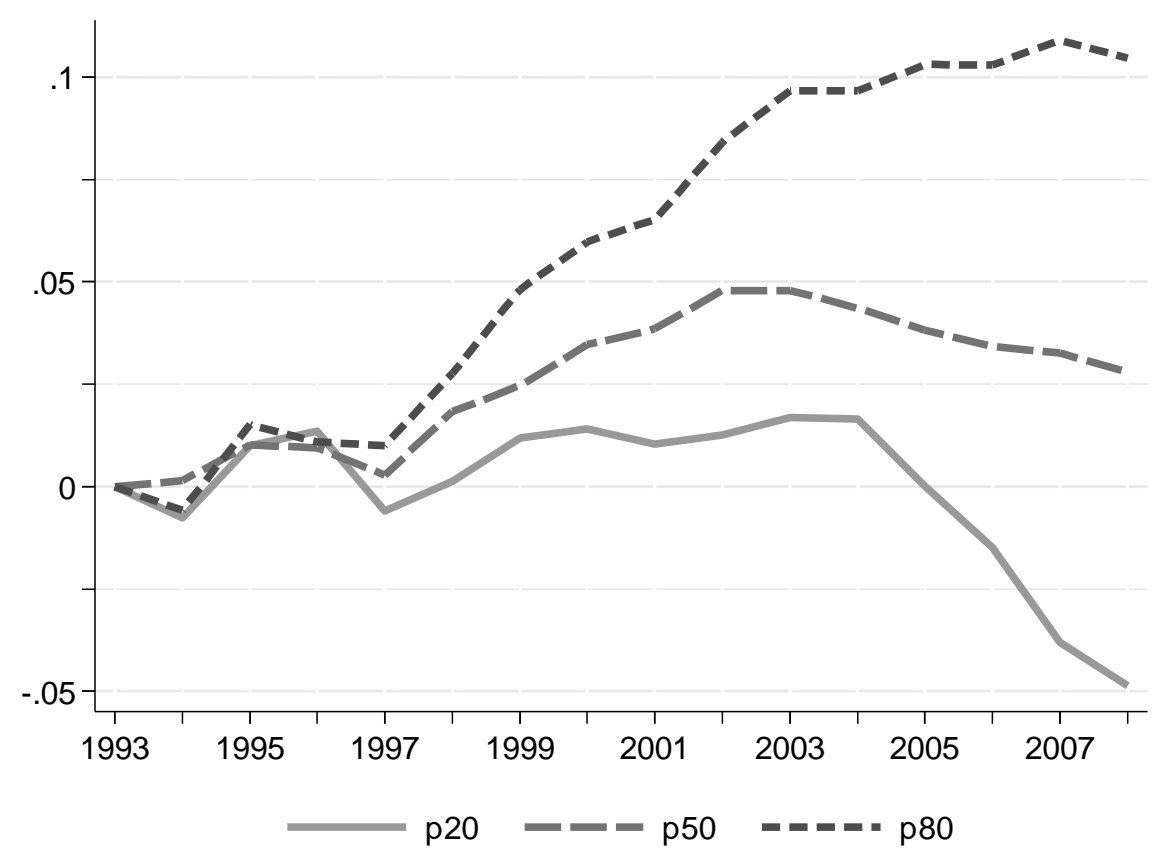

Source: SIAB, Western Germany; full-time, social insurance covered, private sector employees; age 2060; own estimation.

Such country-specific trends present a puzzle to universalist explanations (DiPrete et al 2006; Antonczyk et al., 2012; Oesch, 2013; Baccaro and Pontusson, 2016) and they lead scholars to acknowledge that product and labor markets are ripe with frictions that allow workers to extract rents in addition to returns on their human capital (Grusky and Weeden, 2014; Kristal 
and Cohen, 2017). Because the opportunities for rent extraction are institutionally tied to structural positions (Sørensen, 2000), and the outcomes of power struggles over these positions are determined by historically contingent political coalitions (Thelen, 2004), the redistribution of rents, too, will follow country-specific trajectories. I here analyze one such example: the redistribution of industry rents in the Western German labor market through the introduction of the Economic and Monetary Union (EMU).

Sizeable industry rents have long been shown to exist (Katz \& Summers 1988). In recent years, their study has received renewed popularity to explain the run-away earnings of the very welloff in Anglo-Saxon economies that underwent financialization. Research on these countries documents a dramatic increase in rents paid to employees in the financial sector for the years between the Volcker shock and the Great Recession (Piketty and Saez, 2003; TomaskovicDevey and Lin, 2011; Phillipon and Reshef, 2012; Bivens and Mishel, 2013; Lin, 2015). The additional purchasing power of the well-off argueably also spurs demand for services and thereby stabilizes wages of low wage workers (Autor, 2015).

Financialization and service sector growth, however, have not been dominant trends everywhere. In fact, because economies undergoing financialization rely on external debt, other economies must, by necessity, adopt complementary growth models (Rajan, 2010). This paper extends the study of policy-induced shifts in industry rents to one such country, Germany, where, as I argue, the introduction of the Euro has both deepened the reliance on exports and reduced economic activity in domestically oriented sectors, particularly in construction.

I assess who benefitted from the redistribution of industry rents caused by the introduction of the EMU in relative terms, and who lost. I show that the EMU in Germany indeed affected wages diametrically in the peripheral domestically oriented sectors and in the core exportoriented manufacturing sector and thereby contribute to explain the peculiar fanning out of the German wage distribution.

I use the term 'mercantilist dualization' to characterize this asymmetrical distributive effect of the EMU and to emphasize that this development coincides with institutional changes in German industrial relations (Streeck, 2009; Thelen, 2014), vocational training (Thelen and Busemeyer, 2012), labor market policy (Eichhorst and Marx, 2011), and welfare state reform (Palier and Thelen, 2010), to which comparative research has attested a markedly dualizing thrust (Thelen, 2014). My analysis thereby extends the debate over the distributive implications of the EMU to the intra-national domain. 


\section{Mercantilist dualization: the mechanism}

The comparative capitalisms literature characterizes the German political economy as centered around a strong export-oriented manufacturing sector (Streeck, 1991; Cesaratto and Stirati, 2011; Baccaro and Benassi, 2017). However, the institutions that undergird diversified quality production have become less encompassing in the past decades, giving way to dualization, an uneven pattern of change characterized by relative institutional stability in the manufacturing sector and erosion outside the industrial core (Streeck, 2009; Thelen, 2014). Dualization has distributional implications because its corrosive effects are felt primarily at the fringes of the labor market whereas it preserves standards for the more priviledged labor market insiders (Hassel, 2014; Thelen, 2014).

Germany's dependence on exports for growth intensified between the mid-1990s and the financial crisis. During the same period the profitability of the manufacturing sector improved markedly (Carlin and Soskice, 2009; Baccaro and Pontusson, 2016) which is also reflected in an increasing export wage premium (Baumgarten, 2013; Dauth et al., 2015) and wage growth in tradable manufacturing that outstripped the nontradable sectors (Dustmann et al. 2014; Baccaro and Pontusson, 2016; Baccaro and Benassi, 2017). The EMU has been instrumental to these developments (Nölke, 2016) and, I argue, has reinfored the dualistic cleavage in the German welfare state and production model.

The EMU can be conceived of as a particular solution of the trilemma of macroeconomic policy which stipulates that no country can simultaneously realize more than two conditions from (1) a fixed exchange rate, (2) an independent monetary policy, and (3) capital mobility (Eichengreen and Frieden, 1993; Broz and Frieden, 2001). States that joined the EMU effectively traded sovereignty over interest rates for fixed exchange rates.

In a low-inflation economy such as Germany, fixed exchange rates lead to a currency depreciation that reduces domestic purchasing power and thereby harm the domestic nontradable sectors, in particular since the abdication of an independent monetary policy prohibits the implementation of expansionary monetary policy to counter periods of weak domestic demand. Manufacturing firms will also experience the negative effect of weak domestic demand and a restrictive interest rate, but as they get to trade in a depreciated currency and therefore enjoy distorted terms of trade, they are overcompensated for the negative effects by a counterveiling positive exchange rate effect. ${ }^{1}$ Whereas the net effect of the EMU on profits should therefore be negative for the domestic nontradable sectors, it should be positive for exporters (Frieden, 1994; Henning, 1994; Broz and Frieden, 2001).

\footnotetext{
${ }^{1}$ Whether the exchange rate effect on exporter profits is mediated predominantly through a higher profit margin or a higher quantity of sales depends on the price elasticity of German exports.
} 
In line with this prediction, IG Metall, the dominant union of the export-competing manufacturing sector, expresses a clear preference for the EMU:

“The German economy 'lives' from exports as hardly any other economy does. The customers abroad secure millions of our jobs. The most important customers of German products are Europeans. [...] The common currency has raised the competitiveness in particular of German products. If the highly indebted countries were "thrown out" from the common currency, they depreciate their currencies to improve their competitiveness. The "remainder Euro" which then would only be the currency of the economically strongest EU countries is then under massive pressure to appreciate. A return to the $D$ Mark would even have an immediate massive appreciation as a consequence. This would make German products massively more expensive abroad and therefore lead to a strong slump in foreign demand." (IG Metall, 2011)

The Employers' Association in the Metal and Electrical Engineering Industries, IG Metall's counterpart, echoes this position:

"A return to the D-Mark would be fatal for the Metal and Electrical Industries. The consequence would be a considerable and lasting appreciation that would cost us 30 to 50 Billions in sales - and that for years with corresponding consequences for jobs." (Kupilas, 2013)

In a crisis, when the contingency of a currency regime becomes apparent, its defenders tend to claim universal benefits of the status quo whereas critics of the regime expose its distributive consequences (Carruthers and Babb, 1996). This holds true for the current German debate over the Euro where the federal government underwrites the above cited position in defense of the EMU and equates the interest of the export sector with the general interest by reference to a collective singular, the 'export nation' ${ }^{2}$ (Koselleck et al, 1992). It is this conscious choice of a currency regime in the belief that an undervalued currency and the resulting export surplus would further the general interest which I characterize as mercantilist.

In contrast, critics argue that stakeholders in the core manufacturing sector reap benefits from the EMU while its costs are socialized (Streeck, 2013, 2014; Scharpf, 2015; Höpner and Lutter, 2017). To assess this claim and to examine who benefitted from the redistribution of labor market rents caused by the introduction of the EMU in relative terms, and who lost, it is helpful to explicate the mechanism through which the introduction of the EMU contributed to the fanning out of the German wage structure.

\footnotetext{
2 "The economic success of our export-oriented German economy is fundamentally built on the single European market. About 60 percent of our exported goods go to the European Union. Therefore, we cannot say often enough: The Euro must be stable. The Euro has been successful. It is good for us as an export nation. [...] The Euro brings more economic growth; it brings jobs and thereby prosperity in Germany. That is why we feel the responsibility for our very own interest to make our contribution to secure the future of the Euro. For now and for the next time, that is the central duty. I repeat what I already said yesterday at the opening of the International Motor Show: Everything that serves the goal of securing the future of the Euro is to be done; everything that runs counter to this goal is to be refrained from." (Merkel, 2011; own translations)
} 
I conceive of this as a four-step-process (Figure 2) that also structures the remainder of this article: First, the decision to introduce a monetary union with fixed exchange rates and a single central bank rate distorted real interest and effective exchange rates in Germany, Spain and Ireland, but also Italy, Portugal, and Greece ${ }^{3}$ (section 3). Second, these distortions exerted heterogeneous net effects on the profits of German corporations - positive for manufacturing firms, but mostly negative for firms in the nontradable sector, construction in particular (section 4.1). Third, the additional profits for manufacturing firms (i.e. rents) were shared with employees, increasing their wages. On the other hand, diminished profits in the nontradable sector destroyed worker rents there (section 4.2). Fourth, because manufacturing is a highwage sector and construction and service workers disproportionately earn below-median wages (Figure A1), the redistribution of rents across sectors contributed to moderately increase wage inequality overall (section 4.2).

Figure 2. Path diagram for the causal effect of the EMU on wage inequality in Germany through rent creation and rent destruction.

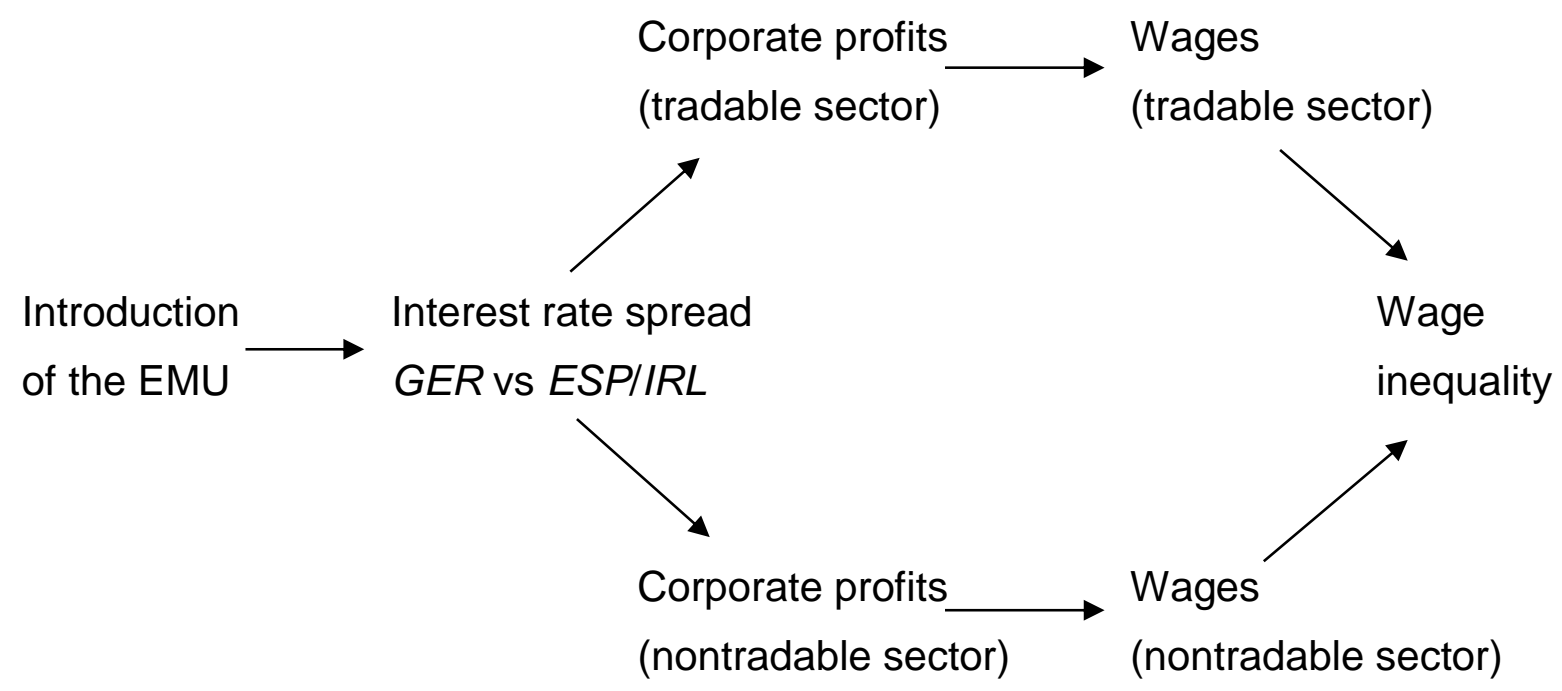

I use this hypothesized mechanism to empirically trace the causal chain that relates cause (i.e. the introduction of the EMU) to effect (i.e. wage inequality) through each of its links. This mechanistic approach amounts to an identification strategy because it rules out confounding through any path that skips at least one link of the causal chain (Morgan and Winship, 2007:

\footnotetext{
${ }^{3}$ I focus on Spain and Ireland, but most of my exposition also applies to Italy, Portugal, and Greece, too. To facilitate a clear narrative and for the sake of brevity, I limit my attention to Spain and Ireland as the exchange and interest rate distortions due to their banking systems translated into a mortgage boom, whereas debt overhang in Portugal, Italy, and Greece took the form of excessive government debt (Lane, 2012; Quaglia and Royo, 2015). A treatment of the Greek case would have further complicated my exposition due to the country's delayed accession to the EMU. Because the trends in Italian and Portuguese real interest rates mirror those of Spain and Ireland, results are very similar when I include their time series in the analysis in section 4.1.
} 
219-242). This approach is particularly appealing when studying extremely rare events that de facto prohibit the construction of a credible control group, such as the introduction of the Euro in Germany (Abell, 2001; Mahoney, 2012).

To implement the mechanistic design, I combine three different research designs in the subanalyses. I resort to comparative narrative explanation (Abell, 2001) based on time series of macrodata for Germany, Spain, and Ireland to assess the effect of the EMU on the spread of real interest rates and to motivate a counterfactual trend (section 3). I then combine an interrupted time-series design with regression models that exploit the longitudinal quality of linked employer-employee panel data to estimate how the EMU-induced imbalances affected corporate profits and wages of individual employees (sections 4.1 and 4.2). Finally, I compare the effect sizes estimated per person across the locations of workers in the wage distribution to assess whether the introduction of the Euro has indeed contributed to the fanning out of wages in Germany (section 4.2). The overall aim of the analysis is thus to identify heterogeneity in the effect of one single cause. I do not seek to explain an effect - rising inequality - by drawing on multiple causes (see Gelman and Imbens, 2013 for this distinction). Hence I also do not claim that the EMU were more important for explaining inequality than other simultaneously emerging trends.

\section{The distortion of interest and exchange rates by the Euro and its effect on manufacturing and construction}

To understand how the EMU created rents in the export sector and destroyed rents in domestic industries it is helpful to briefly recall the monetary order the EMU replaced. During the 1980s and 1990s, many of the countries that were later to join the EMU had pegged their currencies to the $D$-Mark to borrow monetary credibility from it. This implied adopting German inflation targets and mirorring policy decisions taken by the German Bundesbank. The arrangement, however, was a flexible one as it allowed countries to adjust their peg in situations when they were unable or unwilling to follow Germany. Members of the peg nevertheless devalued their currency occasionally to restore their international competitiveness and re-balance their current account by adjusting their exchange rate or to tackle unemployment by choosing a less repressive central bank rate (Henning, 1994; Hancké, 2013; Höpner and Spielau, 2016).

From the perspective of creditors the devaluation option, however, constituted a risk as they would either receive returns and repayment in a devalued currency or would be lending to a debtor exposed to a significant exchange rate risk. Hence, creditors charged a risk premium when lending to countries deemed inflation-prone compared with Germany (Scharpf, 2011; Lane, 2012; Sinn, 2012). This was particularly true for countries such as Spain and Ireland that did not even attempt to defend a peg to the D-Mark. Because they were likely to devalue 
against the $D$-Mark, borrowers there faced a real interest rate significantly above the rate German borrowers paid.

Figure 3 plots the difference between the German real interest rate (i.e. real money market rate) and that of Spain and Ireland. It shows that the cost of borrowing for private debtors in Spain and Ireland lay above the German rate by several percentage points throughout the decade before European leaders decided on a definite roadmap to introduce the Euro. Late in 1991 the negotiations over the establishment of a single currency passed a watershed in Maastricht and were concluded at the Madrid Summit in December 1995 with the passing of the irrevocable plan to fix exchange rates between the member states on January 1 1999. To meet the agreed convergence criteria, prospective member states took explicit measures to restrain wage growth. As intended, these brought inflation down to the German level (Hancké, 2013). The commitment to the stability criteria and the definite plan to abolish currency devaluations removed the perceived additional risk of lending to the historically high-inflation economies. As a result, the associated risk premia vanished between the Maastricht treaty and the formal introduction of the single currency when the project entered its next episode (Figure 3; Scharpf, 2011; Sinn, 2012; Johnston and Regan, 2015).

Figure 3. Difference in real interest rates: Germany - Ireland/Spain.

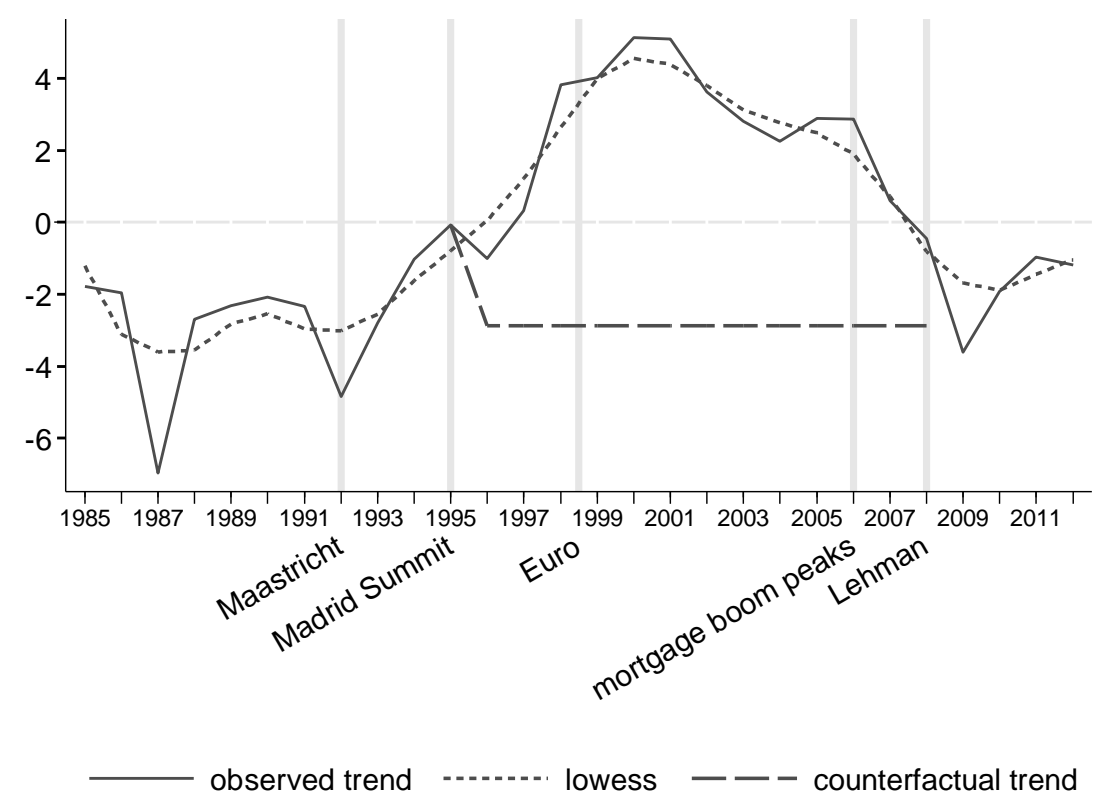

Note: Real interest rate is nominal money market rates minus inflation. Spain and Ireland weighted equally (.5).

Sources: IMF International Financial Statistics, OECD, own calculation. 
The advent of the Euro on January 11999 altered the conditions of membership in three important ways. First, it released governments from the obligation to maintain inflation rates proximate to those of the least inflating members. Second, it removed from candidates the threat of being denied EMU membership. Third, the introduction of the single ECB rate reduced the weight of any single national sector in the central bank's considerations. Each of these changes improved the wage bargaining power of sheltered sectors particularly in member states with weak alternative mechanisms for wage coordination and therefore ended the period of convergence that had begun in Maastricht (Hancké and Rhodes, 2005; Scharpf, 2011; Johnston, 2012; Hancké, 2013).

Under the new conditions, countries that had not adapted their wage bargaining systems to Germany's highly coordinated model but had instead fulfilled the Maastricht criteria through temporary social pacts soon returned to levels of inflation above the EMU average (Hancké and Rhodes, 2005; Scharpf, 2011; Hall, 2012; Höpner and Lutter, 2017). Crucially, the arrival of a unitary nominal central bank rate even rewarded this behavior as it translated high inflation into a low real interest rate whereas inflation rates below the EMU average implied a more repressive real interest (Scharpf, 2011; Hancké, 2013; Pisani-Ferry, 2014). Throughout the period between the introduction of the Euro and the financial crisis private Spanish and Irish debtors indeed borrowed at lower real interest rates than German debtors did - a historic reversal of the previous situation (Figure 3).

From the perspective of investors this was a business opportunity. They could invest in Spain or Ireland with an ordinary interest on their investment and in addition profit from asset price inflation that would continuously drive up the value of their investment as measured in prices of their home country. The prohibition of capital controls within the EMU guaranteed that their investments could be repatriated any time and the fixed exchange rates served them as a freeof-charge insurance against exchange rate risks (Sinn, 2012; Pisani-Ferry, 2014).

The incentive to transfer savings to 'the periphery' of the eurozone was particularly strong for German investors. They could anticipate that they would be repatriating their investments to a country with price stability or even deflation because the very central bank rate that was artificially low for Spain/Ireland was a prohibitive one from the perspective of Germany, the laggard with respect to inflation (Scharpf, 2011; Hancké, 2013; Nölke, 2016). The central bank rate that fed the boom in the countries with high-inflation inhibited asset price hikes in Germany, and thus provided Germans with an additional reason to transfer savings abroad. Figure 4 plots the German, Spanish, and Irish current account balances over time and shows net capital exports from Germany and net capital inflows for Spain and Ireland between the introduction of fixed exchange rates and the onset of the financial and EMU crisis in 2009 (Scharpf, 2011; Sinn, 2012; Ó Riain). 
Figure 4. Current account balance as percentage of GDP.

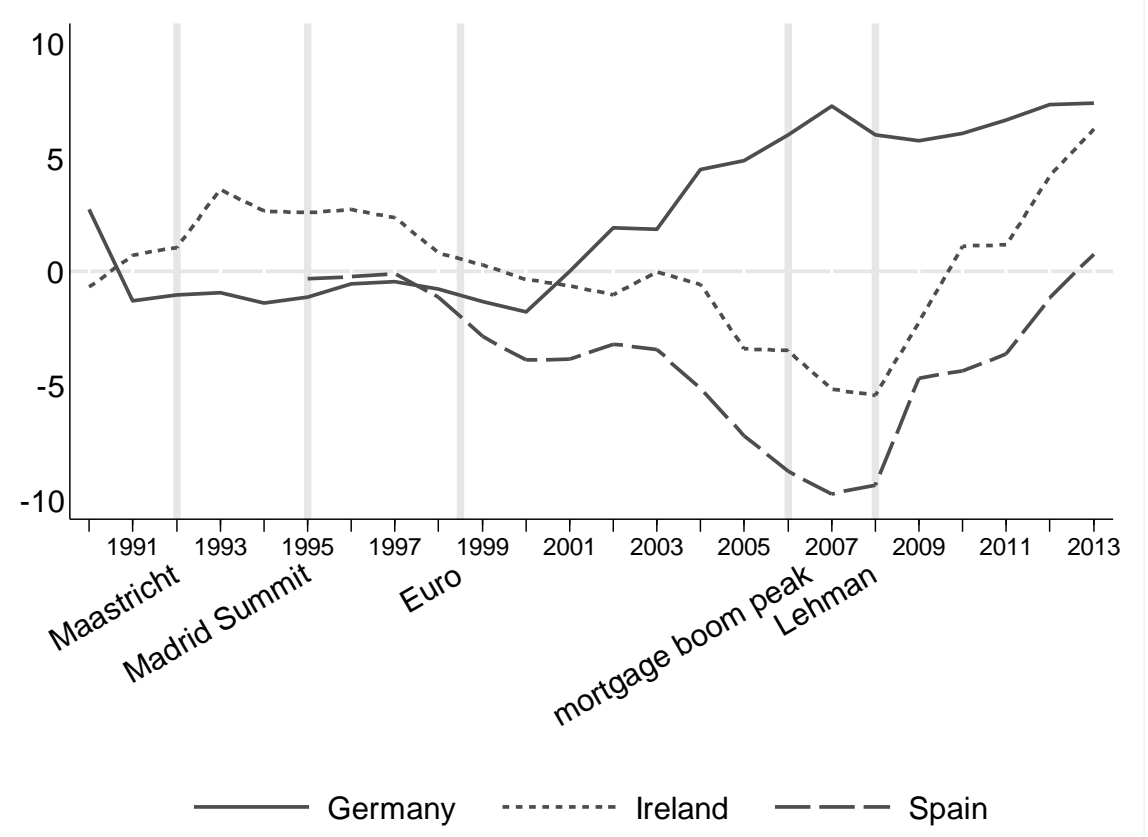

Source: IMF International Financial Statistics.

These years are known to be the years of the real estate boom in Spain and Ireland. The causal role of the Euro and its interaction with these countries' banking systems for the build up of mortgage-based asset price bubbles is undisputed (Fernández-Villaverde et al., 2013; Ó Riain, 2014; Quaglia and Royo, 2015). The debate on how to restore Spain and Ireland's competitiveness that followed the EMU crisis has also established that inflation during the boom years has damaged the competitiveness of the Spanish and Irish traded goods sectors (Hall, 2012; Sinn, 2012).

That the effect of entering the monetary union in Germany, too, differed strongly between industries, is not equally accepted, however. Whereas political leaders, employer representatives and the manufacturing union acknowledge the EMU's role for Germany's current account surplus when they argue that a currency revaluation would put the competitiveness of German traded goods at stake (see quotes in section 2), the relationship between the introduction of the EMU and the slump of the German construction sector has gone largely unnoticed (but see Pisani-Ferry, 2011; Scharpf, 2011; Sinn, 2012).

Figure 5 shows that the dramatic take-off in Spanish and Irish construction began when EMU membership was secured and that it ended in 2007 when the real estate bubble burst. The boom period coincides with the period when the cost of borrowing in Spain and Ireland fell below that in Germany (Figure 3) and when Germany became a net exporter of savings (Figure 4). It also coincides with the erosion of Spain and Ireland's manufacturing sectors' 
competetiveness relative to Germany (Figure 6) and a decline of manufacturing's contribution to both Spanish and Irish GDP (Figure 5).

Figure 5. Value added by industry, as percentage of GDP.

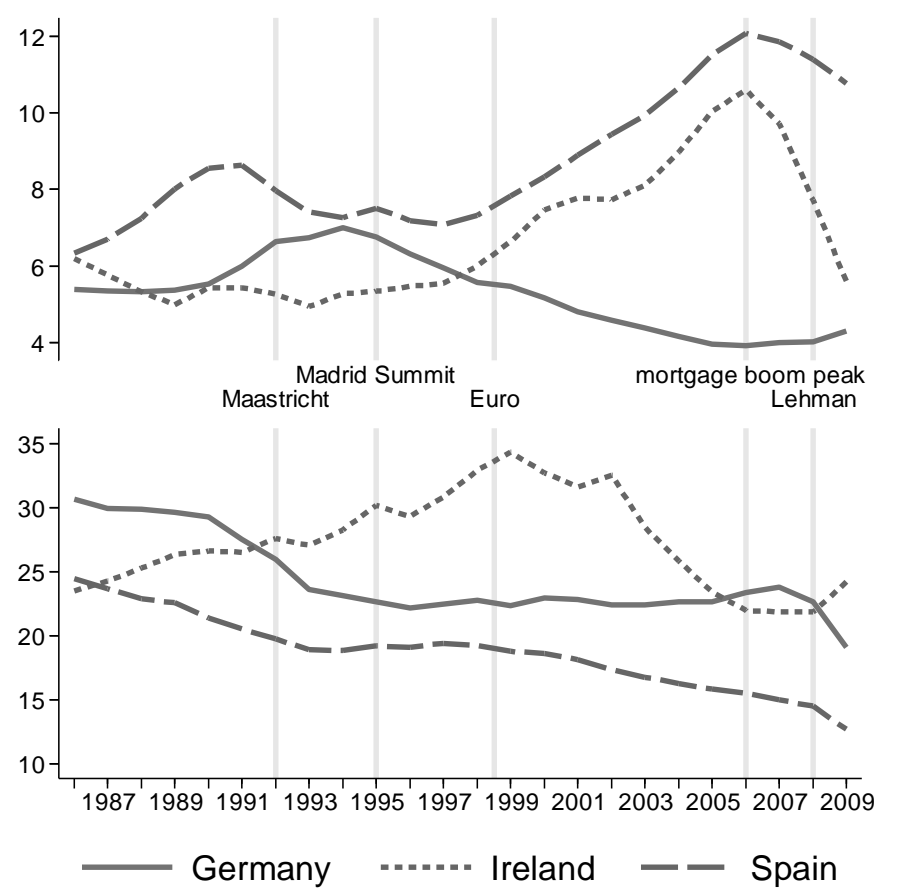

Source: OECD Structural Analysis Database

Figure 6. Real effective exchange rates.

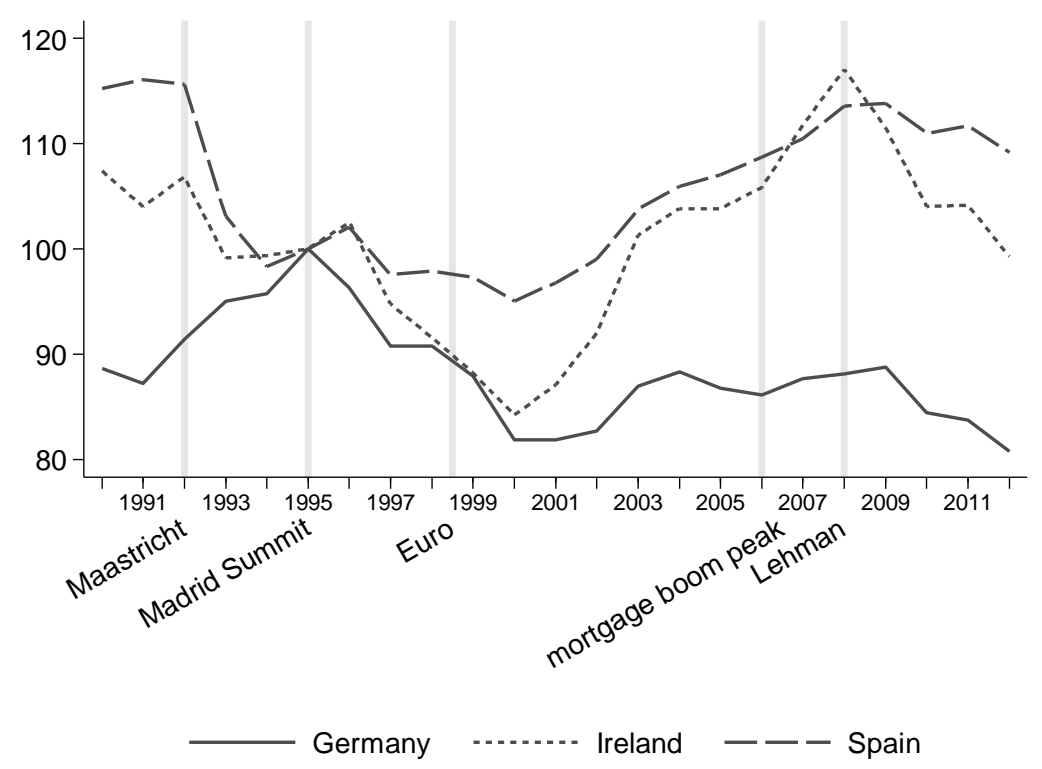

Note: $100=1995$.

Source: IMF International Financial Statistics. 
Germany, in turn, saw a marked shift away from manufacturing in the years after reunification that came to a halt in the mid-1990s (Figure 5). Throughout the years between the advent of the EMU and its crisis, the contribution of manufacturing to German GDP remained constant at a share of more than 20 percent despite the secular tertiarization trend. After a brief postreunification boom, the German construction industry began its decline in the years after Maastricht when real interest rates in Ireland and Spain converged to the German level. After the advent of the Euro the decline continued unabated and reduced construction's output significantly below pre-reunification levels. The demise of German construction only stopped in 2006/07 when the mortgage boom in Spain and Ireland ended (Figure 5) and the net export of German savings did not increase for the first time since the fixing of exchange rates in 1999 (Figure 4) and began to increasingly consist of public credit (Sinn and Wollmershäuser, 2012).

Data on construction orders and house prices in Germany that extend beyond the financial crisis when the outflow of private savings from Germany to Spain/Ireland reversed as private investors repatriated their capital to Germany (Sinn and Wollmershäuser, 2012) provide additional evidence for the nexus between imbalances in the Eurozone and the state of the German construction sector (Figure 7). House prices and the value of construction orders (both indexed to 2010) reached a trough in 2004-2006 when the mortgage boom in Spain and Ireland was approaching its peak. After dormancy throughout the period after the introduction of the Euro and the burst of the mortgage bubble the German real estate market surged. This was accompanied by rebounding construction orders (Figure 7) and aided by the unitary central bank rate mechanism, that had implied artificially high real interest rates when Germany showed low inflation and growth, but now brought artificially low interest rates as Germany showed strong growth relative to the Eurozone's 'periphery'.

Given these diametrically opposed developments in manufacturing and construction in Spain/Ireland and Germany, and given that these can plausibly be argued to have their common cause in the reversal of the real interest rate gap (Frieden, 1994; 2015), I propose that as the loss of competitiveness of Spain and Ireland's manufacturing sectors (Figure 6) has been a price paid for the construction boom (Figure 5), so has German manufacturing's success in export markets come at the cost of the demise of German construction (Figure 5) and weak domestic consumption in general. All of these developments are bound together by the flow of savings from Germany to the periphery of the Eurozone. These were initiated by the introduction of the EMU and sustained by the resulting mortgage boom that continued unfettered by currency revaluations and led into an ever deeper overvaluation of Spanish and Irish traded goods in international markets as well ever more artificial terms of trade that created rents for German manufacturing (Figure 6). Because manufacturing employees tend to be workers with high wages whereas construction and service sectors tend to pay below- 
median wages, this redistribution of rents from domestic non-traded sectors to manufacturing has potentially contributed to the fanning out of the German wage distribution.

Figure 7. Construction orders and house prices, Germany, 1993-2015.

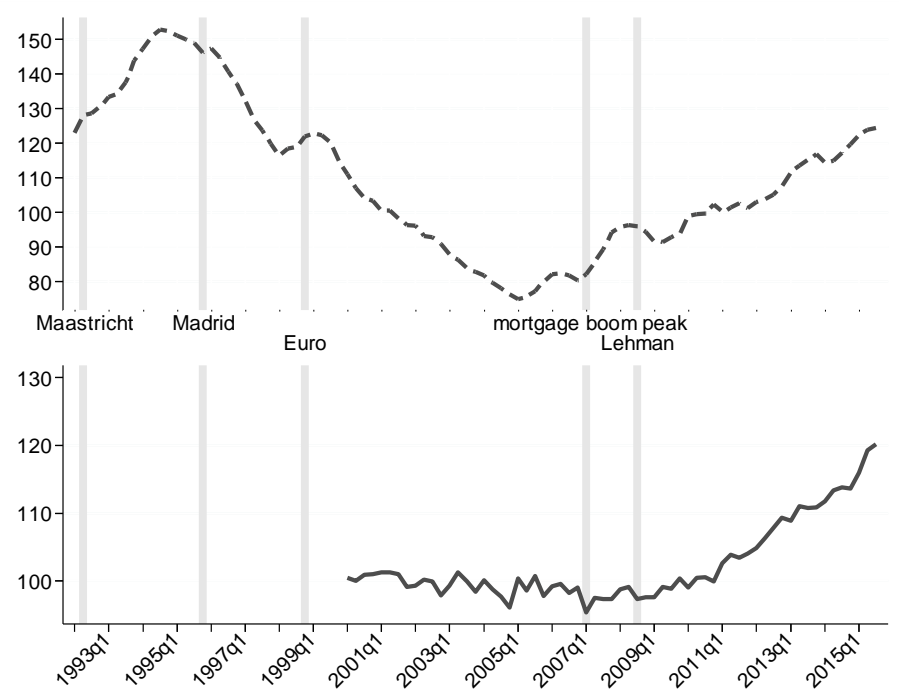

Note: $100=2010$. Source: Statistisches Bundesamt, Auftragsbestand im Bauhauptgewerbe (Wert), Häuserpreisindex für Wohnimmobilien.

\section{A redistribution of industry rents}

To scrutinize this argument and to trace the impact of the EMU on wage inequality further along the causal mechanism that runs from the macro level to the organizational level and from there to the individual level (Figure 2), I now analyze the effect of the EMU on firms' profits (4.1) and then turn to the process of rent sharing by which the shifts in firms' profits is carried on to employees' wages and thereby the wage structure (4.2).

\subsection{Heterogeneous effects of the EMU on corporate profits}

\subsubsection{Modeling strategy and data}

Based on the literature, I argue that the reversal of real interest rate differences in combination with fixed exchange rates have brought about the divergent effects of the EMU on manufacturing and domestic industries, construction in particular. Figure 3 shows how once EU member states pursued serious plans to enter into a monetary union, the cost of borrowing in Spain and Ireland first rapidly converged towards the German level and then even fell significantly below it. The dotted line in Figure 3 plots the average difference between Germany and Spain/Ireland in real interest rates observed during the decade prior to the 1995 Madrid Summit where the definite plan to enter into a currency union on January 11999 was declared irreversible. I conceive of this as a rough approximation of the trend that would have been observed if the member states had not embarked on the project of forming the EMU. 
Although I acknowledge that the construction of counterfactual trends at the macro level always remains a partly speculative exercise, I consider it reasonable to assume that the difference in real interest rates would not have reversed without the EMU given the substantive argument provided in section 3. Absent the EMU this difference would likely have continued to trend somewhere around the observed average of the decade prior to the Madrid Summit. This assumption is supported by the empirical observation that the difference in real interest rates between Germany and Spain/Ireland in 2009 indeed reverted to this trend line once the financial and EMU crises erupted in late 2008 and destroyed the trust of creditors that their capital could be safely repatriated from Spain and Ireland. ${ }^{4}$

The historic reversal of the difference in real interest rates between Germany and Spain/Ireland in the 1990s hence represents a significant deviation from the previous situation and permits the implementation of an interrupted time-series design (ITS). ITS uses longitudinal variation in firms' macroeconomic conditions to draw inferences on the impact of a policy change such as the introduction of the Euro (Morgan and Winship 2007; Gangl, 2010). These inferences are more credible than such drawn from comparative designs that exploit between-country variation as this within-country design rules out confounding by factors (such as industrial relations, welfare state regime, etc.) that can be considered constant, at least when compared with the dramatic changes in real interest rate differences that occurred over a relatively short period (Ziefle and Gangl, 2015: 567). The ITS design is improved when combined with panel regression that suspends identification from variation between country-years and instead estimates the effect of a change in the real interest rate spread from year-to-year fluctuations in profits of one and the same firm (Gangl, 2010: 29).

The integretation of China and Central and Eastern Europe into trade with Western Europe also occurred rapidly and during the 1990s and 2000s and may also have had disproportionate effects on manufacturing profits (Dauth et al., 2014). I therefore control for the increasing exchange with these emerging trade partners. A seemingly straightforward measure for this would be changes in the volume of Germany's trade with these countries. However, because the EMU potentially distorted not only internal terms of trade but also Germany's trade with Eastern Europe and China, controling for the development of German trade might not only have the desired effect of controling for a potentially confounding development, but could also over-control away a part of the EMU's effect on manufacturing and thus bias the estimates of substantive interest here (Elwert and Winship, 2014). In this situation, I proxy the increase in trade between Germany and Eastern Europe and China that would have occurred if Germany's terms of trade had not been distorted by accession to the EMU through the increases in trade

\footnotetext{
${ }^{4}$ Note that the spread did not remain at this counterfactual trend for long because the ECB soon intervened in financial markets with 'non-standard monetary policy measures' with the stated goal of reducing differences in the cost of borrowing within the Eurozone.
} 
that occurred between Eastern Europe and China on the one hand and Switzerland and Sweden on the other (see Dauth et al. 2014 for a related approach). Switzerland and Sweden provide credible proxies because they are similarly structured open economies in geographic locations similar to Germany's, but with exchange rates that were not distorted by accession to a fixed exchange rate regime. ${ }^{5}$ In addition, I control for GDP growth to net out business cycles that strongly impact firms' profit situation. This results in the following regression equation:

PROFITS $_{j t}=\beta_{0}+\beta_{1} x_{1}+\beta_{2} x_{1}^{2}+\beta_{3} x_{2}+\beta \operatorname{IND}_{j} \times x_{2}+\gamma_{1} x_{3}+\gamma \operatorname{IND}_{j} \times x_{3}+\alpha_{j}+\epsilon_{j t}$

Where PROFITS $j$ are profits of establishment $j$ in year $t ; \beta_{0}$ is a constant; $x_{1}$ is annual growth in German GDP; $x_{2}$ is annual growth in trade between Central and Eastern Europe/China with Switzerland/Sweden; with $\beta_{3}$ as the main effect and $\boldsymbol{\beta}$ as a vector of industry-specific effects; $x_{3}$ is the difference in the real interest rates of Germany and Spain/Ireland (Figure 3) - the independent variable of interest here $-v_{1}$ is its main effect and $\boldsymbol{y}$ a vector of coefficients for $\mathrm{IND}_{j} \times x_{3}$, a vector of interaction terms that allow for the crucially important heterogeneity of that effect across industries; $\alpha_{j}$ are establishment fixed-effects and $\epsilon_{j t}$ is the establishment-year specific error that I allow to be clustered in industry-years.

I fit this model to data on private sector for-profit firms from the IAB Establishment Panel, a representative survey of Western German establishments that employ at least one person covered by social security (Fischer et al., 2009). More than 4000 Establishments at any given year were re-interviewed annually since 1993 about various business-related topics on the basis of a random stratified sampling design. The study was extended to Eastern German establishments in 1996, but I restrict the analysis to Western Germany in order to minimize noise in the data that results from the turbulant adoption of a market economy in Eastern Germany during the 1990s.

I computed real interest rates for Germany, Spain and Ireland from annual information on nominal money market rates and inflation rates obtained from IMF International Financial Statistics. Annual rates of growth in Switzerland's and Sweden's trade (imports and exports; both country weighted equally at one half) with China, Bulgaria, Czech Republic, Estonia, Hungary, Latvia, Lithuania, Poland, Romania, Slovakia, Slovenia were computed from the United Nations Commodity Trade Statistics Database.

The resulting time series were merged to the Establishment Panel where firms were asked annually to self-assess their profit situation on a 5-point Likert-scale ranging from 0 ('insufficient') to 4 ('very good'). If this information was missing in a year between two complete

\footnotetext{
${ }^{5}$ Note, however, that in practice it makes no difference whether I use trade between China/Eastern Europe and Germany or Switzerland/ Sweden. The results are virtually identical.
} 
observations, I imputed a linear trend and only deleted establishment-years with non-response on profits if they intermitted more than one year or occurred in an establishment's first or last wave. Establishments are classified by seven broad industry categories. I split establishments by assignment of a new ID whenever interviewers reported that they surveyed 'a different unit than last year' to ensure the viability of the fixed-effects approach. For the same reason, a new ID was assigned on the rare occasion of a change in the industry variable. A replication package documents these and all other decisions in full detail and is publicly and permanently available at the Harvard Dataverse (Author, 2016). In all analyses I use weights to account for the stratified sampling design. Standard errors are robust to heteroskedasticity across establishments and industry-years. The resulting dataset comprises 17,002 establishments with on average 3.7 years of data.

\subsubsection{Results}

Figure 8 plots the substantively interesting parameter for each industry: the marginal effect of a one percentage point increase in the difference between Germany's and Spain's/Ireland's real interest rates on profits (see Table A1 for the full table). The results suggest that a positive change in this difference increased profits only for manufacturing firms but had no such or even negative effects for firms in all other industries. Notably, and as suggested by the above argument, the coefficient for construction lies at the opposite end of the range of estimated effect sizes. This suggest that net of (low) overall growth the convergence of interest rates in the Eurozone (read: the reduction of an initially large negative value and hence the increase in the difference between Germany's and Spain's/Ireland's rates) indeed had a positive effect on manufacturing but a significantly more negative effect on all domestic sectors (except utilities). This finding calls into question statements such as the above cited (section 2), that extrapolate from the EMU's effect on the traded goods sector to the nontradable sector and corroborates scepticism against such generalizations (Streeck, 2014; Scharpf, 2015; Höpner and Lutter, 2017).

With both a counterfactual trend in the interest rate difference and an empirical estimate for the industry-specific effects of this factor on profits now at hand, the simulation of a counterfactual trend in profits for manufacturing and construction is straightforward. ${ }^{6}$ It allows for a more intuitive assessment of the heterogeneous effect of the introduction of the EMU as it visually corroborates that the EMU-induced distortion of interest and exchange rates created rents for corporations in the export sector and destroyed rents in the construction industry in relative terms (Figure 9).

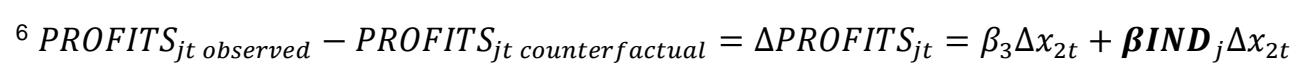


Figure 8. Industry-specific marginal effects on profits of the inversion of the difference between Germany and Spain/Ireland in real interest rates.

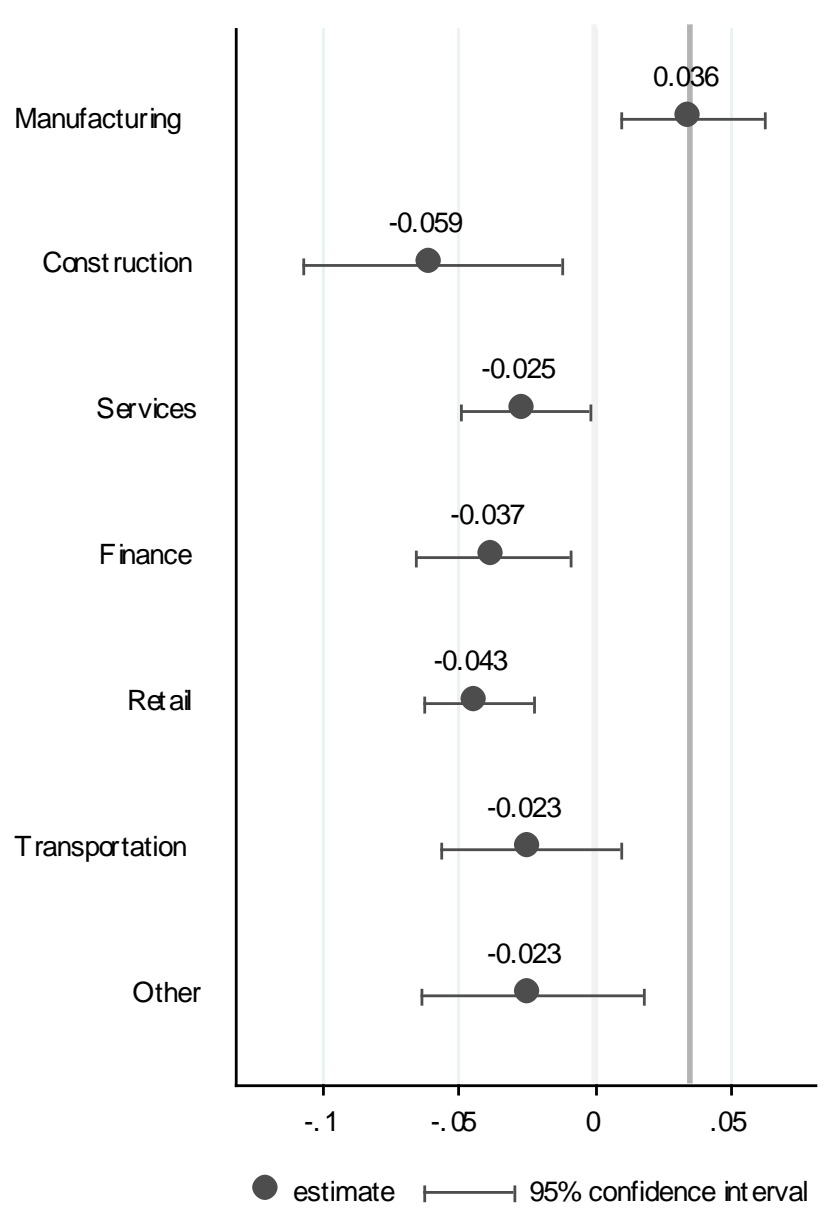

Note: Estimates for a one percentage point change from fixed-effects panel regression; errors clustered in industry-years; $\mathrm{N}=62,237$; see table $\mathrm{A} 1$ for full regression table. 'Other' is agriculture, mining, and utilities.

Source: IAB Establishment Panel, Western Germany, 1993-2008; own calculation. 
Figure 9. Profit situation in manufacturing and construction, observed and simulated trends.

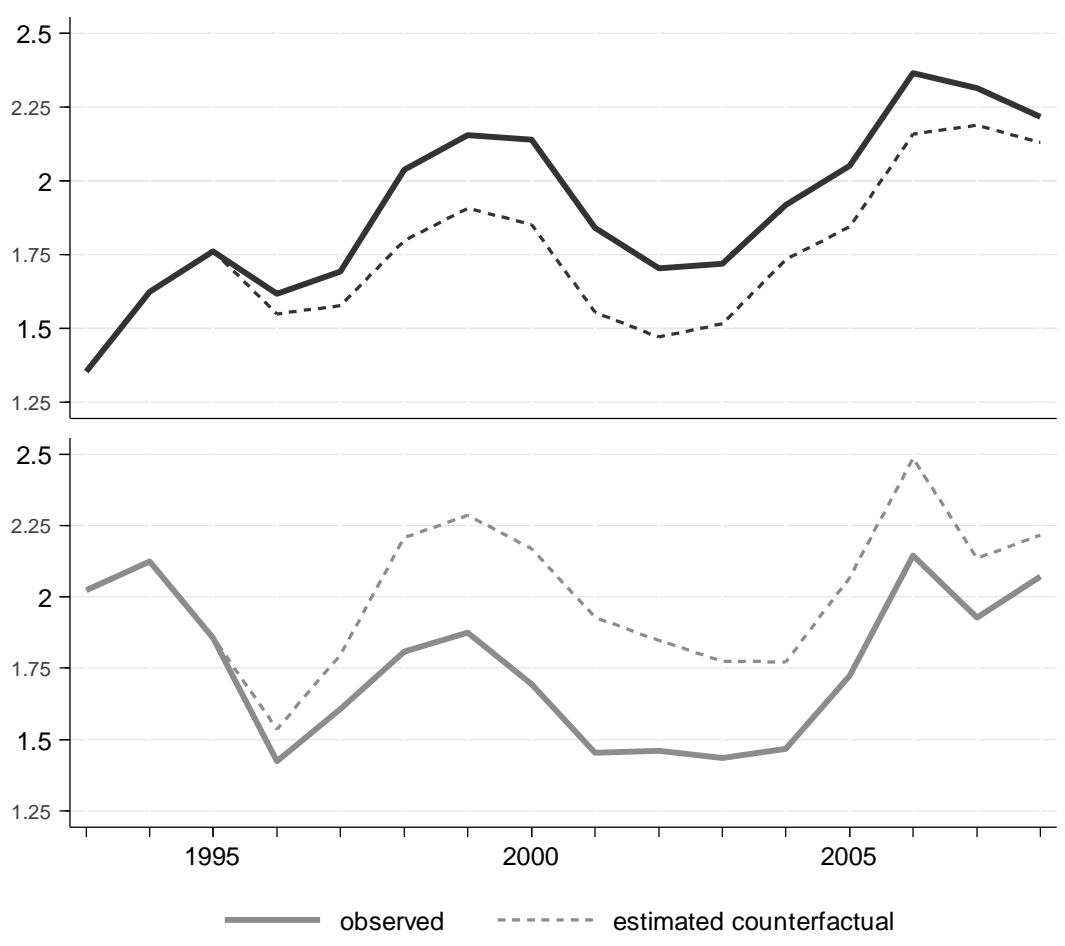

Note: Vertical axis is 5-point Likert-scaled; 0 =insufficient, $1=$ (just) sufficient, $2=$ satisfactory, $3=$ good, 4=very good. Source: IAB Establishment Panel, Western Germany, 1993-2008, own calculation.

\subsection{Rent sharing and the Euro's effect on wage inequality}

\subsubsection{Modeling strategy and data}

For the impact of the introduction of the Euro to reverberate to the wage distribution, corporate profits must, however, also causally affect wages (Figure 2). A large body of economic research on rent sharing suggests that they do (Card et al., 2016 for a review). To validate this step in the causal process that I seek to trace, and to obtain an empirical estimate of the strength of this relationship, I exploit the IAB Establishment Panel's potential to be extended to a linked-employer-employee panel data set (Heining et al., 2014). The availability of a longitudinal survey at the establishment level in combination with longitudinal administrative data on all employees covered by social insurance at these very same establishments permits the implementation of the following distributed lag (three-way) fixed-effects panel regression model to address this question:

$\ln W A G E_{i j k t}=\alpha_{j}+\lambda_{t}+\boldsymbol{\beta} \boldsymbol{X}_{i t}+\eta_{o c c \times p e r i o d}$

$$
+\beta_{1} \text { PROFITS }_{j t}+\beta_{2} \text { PROFITS }_{j t-1}+\beta_{3} \text { PROFITS }_{k t}+\beta_{4} \text { PROFITS }_{k t-1}+\beta_{5} \text { PROFITS }_{k t-2}+\epsilon_{i j k t}
$$

Where $W A G E_{i j k t}$ is the real wage earned by employee $i$ in establishment $j$, industry $k$ and year $t$. Again, the establishment fixed-effects $\alpha_{j}$ bring the crucial advantage of controlling away any 
temporally stable establishment characteristics that may confound the effect of corporate profits on wages. Year fixed effects $\lambda_{t}$ adjust for the economy-wide wage trend.

In order to absorb changes in an establishment's workforce composition that might systematically accompany changes in profits, I control for $\boldsymbol{X}_{i t}$, a vector of person characteristics, namely nationality (Non-German or German), gender, fully interacted with potential experience (squared and cubed), worker type (white collar / skilled blue collar / unskilled worker), education (no vocational training / vocational training, no Abitur / vocational training, with Abitur / college degree), fully interacted with potential experience (squared and cubed), and education interacted with four four-year time periods. To the same end I control for 336 detailed occupations wherein I allow the effect of each occupation to vary across four four-year time periods as a set of $336 \times 4$ fixed effects $\left(\eta_{\text {occ } \times \text { period }}\right.$ ). This non-parametric control strategy absorbs economy-wide changes in the returns to skill, independent of the functional form in which they occurred and thereby statistically isolates the process of rent sharing from general developments that altered the market price of skills such as skill-biased technological change, trade, or immigration.

I allow for rent sharing through two distinct channels. First, processes such as nonrecurring bonus payments by which corporations share profits with employees that work for them. I assume that these kinds of remunerations are paid out in the same year that an increase in corporate profits occurred or in the following year.

In the German context it is vital to also allow for rent sharing through an industry-mechanism as this is the level where collective wage bargaining takes place. I allow for this sort of rent sharing to unfold over three years given that collective wage agreements are typically negotiated for a duration of up to 24 months. The lags remove 1993 and 1994 as well as establishments' first survey year from the analysis which is why the analysis is conducted on a smaller number of establishment-years than the above reported regression (4.1).

This model identifies the causal effect of corporate profits on workers' wages and thus rent sharing if unobserved factors do not simultaneously impact corporate profits and wages. The tenability of this assumption is supported by the idea that all for-profit corporations seek to maximize profits so that actual variation in profits will come from economic shocks which, I want to argue, can reasonably be considered exogeneous to unmeasured time-varying establishment and person characteristics that predict wages. For correct estimates of uncertainty due to sampling error, I allow for error clustering in establishments and industryyears. I use an iterative algorithm to estimate this model (Correia, 2015).

The model is fit to the linked employer-employee panel dataset (LIAB) that results from the matching of IAB Establishment Panel's annual waves with annual administrative data from which I obtain all person characteristics, including wages and bonus payments. These data 
stem from the notification procedure that obliges employers to report wages for the calculation of social security contributions. Wages are inflation-adjusted to 2010 Euros. I restrict the sample to non-apprentice employees of age twenty to sixty and to full-time workers who earn at least 600 Euros per month because the data lack more explicit information about hours worked.

A major limitation of these data is the censoring of wages at the social security contribution ceiling which affects 16.5 percent of observations. To avoid selection bias, I impute this information by Tobit regressions fit separately for each of the $8 \times 4$ possible combinations of industry and education group drawing on establishment and person characteristics, namely calender year, federal state, number of full-time employees in the establishment (logged), average wage (logged), proportion of observations censored, profit situation, the employee's experience (squared and cubed), gender, fully interacted with experience (squared and cubed), nationality and occupation (similar to Card et al., 2013). I top-coded the very few imputed values above three times the value of the contribution ceiling because I consider the imputation model ill-suited to predict extreme outliers. The results are robust to instead simply imputing 1.5 times the value of the contribution ceiling. The education variable was harmonized and imputed using longitudinal information from the same person following Fitzenberger et al. (2006: 415-417). The analysis sample encompasses 9,669,681 observations from 2,613,105 individuals and 11,524 establishments.

\subsubsection{Results}

The results provide evidence for rent sharing of moderate strength (Table 1). A one point increase in a firm's profit situation (e.g. from satisfactory to good) leads to a wage increase of half a percent in that firm in the same and the following year. Rent sharing through collective bargaining has stronger effects. A one point increase in average profits in an industry causes wages in that industry to rise by 1.4 to 1.8 percent in the year of the increase and the following year. The full 2 percent effect, however, only unfolds in the second year after the change in an industry's profit situation. This makes sense given that collective wage contracts regularly run for approximately two years and thus postpone the occurrence of rent sharing. Note that the firm- and industry-level processes will often occur simultaneously and their effects add up. 
Table 1. Rent-sharing: effects of changes in corporate profits on real wages, estimates from a distributed-lag threeway fixed-effects regression.

\begin{tabular}{|c|c|c|}
\hline & Coef. & s.e. \\
\hline \multicolumn{3}{|l|}{ Establishment-level profits } \\
\hline unlagged & $.005^{* \star}$ & .0007 \\
\hline one-year lag & $.005^{\star \star \star}$ & .0006 \\
\hline \multicolumn{3}{|l|}{ Industry-level profits } \\
\hline unlagged & $.018^{*}$ & .0091 \\
\hline one-year-lag & .014 & .0073 \\
\hline two-year-lag & $.020^{*}$ & .0075 \\
\hline Establishment fixed-effects & \multicolumn{2}{|c|}{ Yes } \\
\hline Year fixed-effects & \multicolumn{2}{|c|}{ Yes } \\
\hline Occupation-by-period fixed-effects & \multicolumn{2}{|c|}{ Yes } \\
\hline Employee controls & \multicolumn{2}{|c|}{ Yes } \\
\hline$N=$ & \multicolumn{2}{|c|}{$9,669,681$} \\
\hline
\end{tabular}

Notes: ${ }^{*} \mathrm{p}<.05,{ }^{* *} \mathrm{p}<.01,{ }^{* * *} \mathrm{p}<.001$ Errors clustered in employees, industry-years and establishment-years. Employee controls: worker type: unskilled / skilled blue collar/ white collar; education: no voc. training/ voc. training without Abitur / voc. training with Abitur / college degree, all categories fully interacted with both period and potential experience (squared and cubed); gender, fully interacted with experience (squared and cubed); nationality. See Table A2 for parameters of control variables.

Source: LIAB 1995-2008; full-time, social insurance covered, private sector employees, age 20-60.

In combination with the previously derived counterfactual profit trends (Figure 9) these estimated effect sizes now also allow for a simulation of counterfactual wage trends. ${ }^{7}$ Figure 10 plots these for manufacturing and construction based on wage information from the Sample of Integrated Employment Biographies $(\mathrm{SIAB}) .{ }^{8}$ Average real wages in manufacturing increased significantly between the mid 1990s and 2008. This contrasts with construction where wages followed a downward trend that only came to a halt in 2006. The plotted counterfactual trends suggest that this divergence would have been less pronounced absent the EMU.

\footnotetext{
${ }^{7} \Delta$ InWAGE $_{i j k t}=\beta_{1} \Delta$ PROFITS $_{j t}+\beta_{2} \Delta$ PROFITS $_{j t-1}+\beta_{3} \Delta$ PROFITS $_{k t}+\beta_{4} \Delta$ PROFITS $_{k t-1}+$ $\beta_{5} \triangle P$ ROFITS $k t-2$

8 The SIAB is a 2 percent random sample drawn from the same dataset that provides the employeelevel data in LIAB. I prepared the SIAB in similar ways as the LIAB, see Author (2016) for details.
} 
Figure 10. Real monthly wages in manufacturing and construction, before taxes, observed and simulated trends.

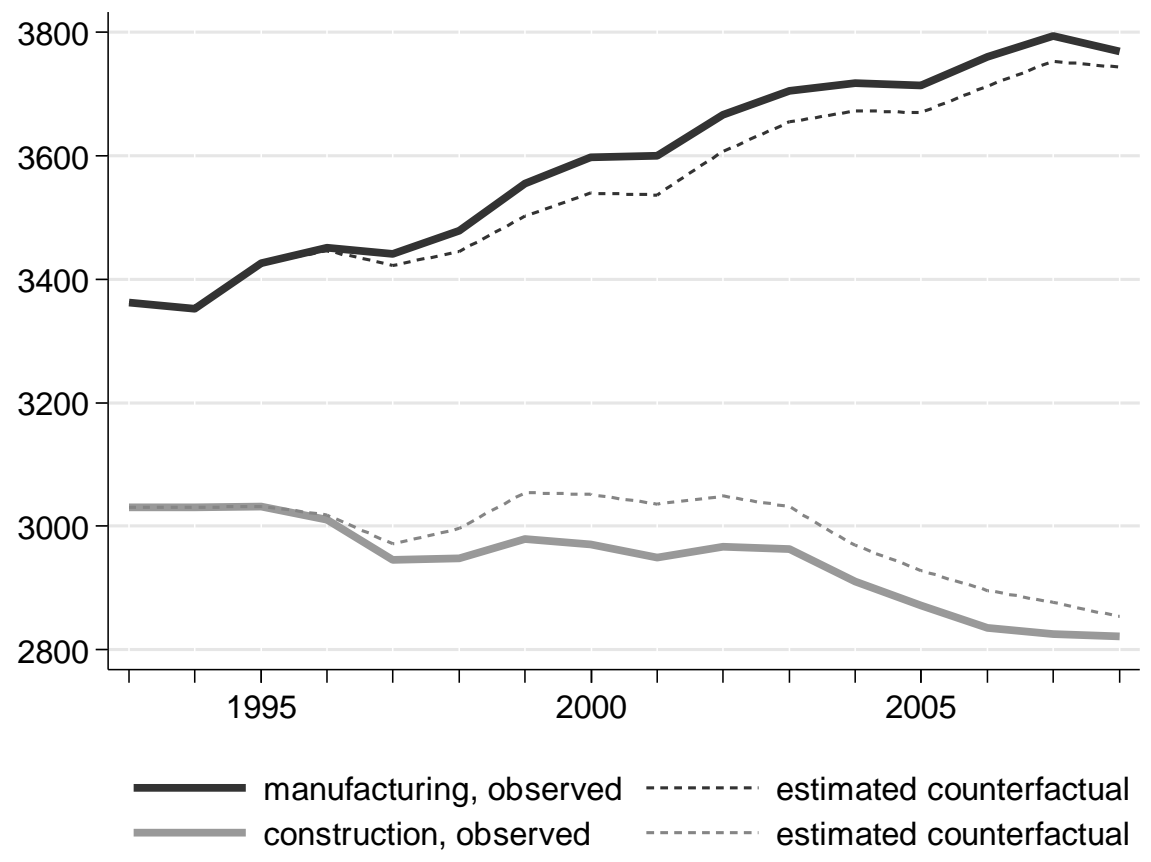

Note: Western Germany, full-time, social insurance covered employees, age 20-60; deflated by CPI (2010).

Source: SIAB 1993-2008, own calculation.

For the sake of brevity and conciseness, my narrative so far focussed on the contrast between manufacturing and construction. I now assess whether the theme of the Euro as an inequality generating force still holds up when we broaden the scope to all industries using a binned scatter plot of effect sizes for the year 2004, when the mortgage booms in Spain and Ireland were in full swing. For the plot I group persons into 100 equally populated wage percentile bins. From the models above, I obtained predicted effect sizes for every single person. Figure 11 plots the average estimated effect size for each of the 100 bins relative to bin 50 . It thus informs us about where in the wage distribution persons are located who were loosers (in relative terms) of the EMU-induced rent shift and where the winners can be found. These overall results show that estimated effect sizes are clearly associated with an employee's position in the wage distribution. They are disproportionately negative for persons with low wages and disproportionately positive for those in the upper part of the distribution. Hence, the redistribution of rents that was caused by the imbalances in the Eurozone has pulled those at the bottom of the German wage distribution further below the median and has lifted those above the median further up. This pattern mirrors the fanning out of the German wage distribution (Figure 1) to which the introduction of the Euro apparently has contributed. 
Figure 11. Estimated wage effect of the EMU across 100 percentile bins, for 2004.

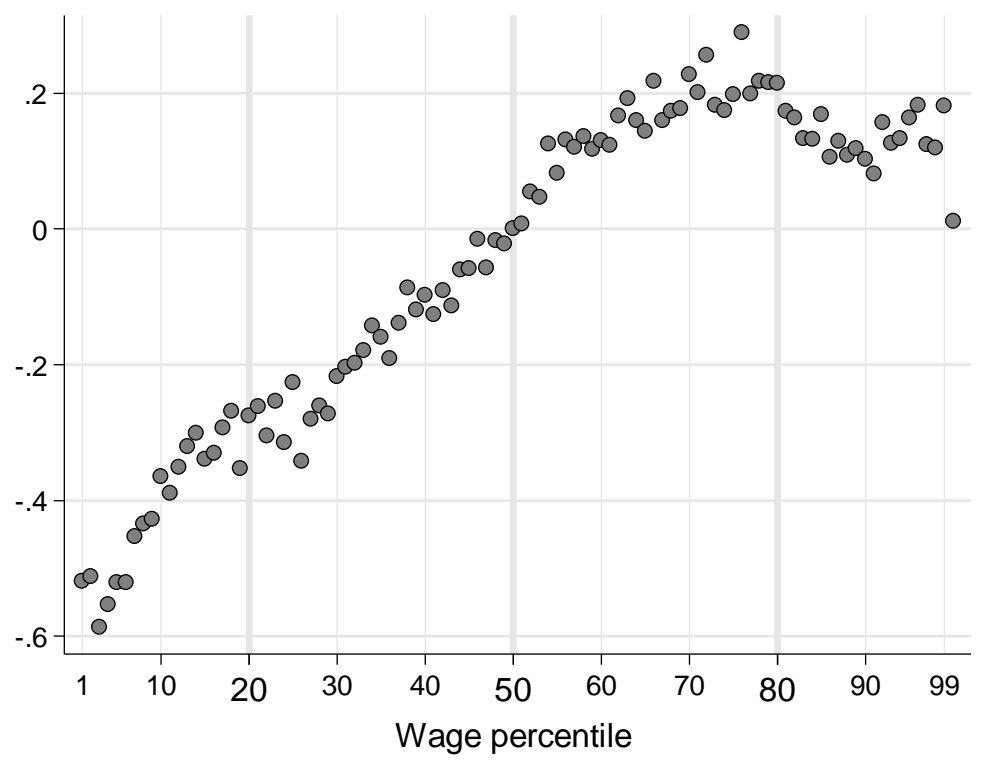

Note: $0=$ p50. Sources: SIAB, LIAB, own calculation.

\section{Conclusion}

The controversy over the EMU so far has mostly focussed on which countries gain and which countries loose. This has left underexposed that the EMU may serve certain interest groups better than others also at the national level, in particular in creditor states (Streeck, 2014; Frieden and Walter, 2017). Using a mechanistic research design, I showed for Western Germany that during the years between its introduction and the financial crisis the costs and benefits of the Euro were indeed distributed unequally across industries. First, I illustrated how the EMU distorted real interest and real exchange rates both in Germany and in Spain and Ireland. Second, I showed that these imbalances redistributed industry rents from the nontradable sector, in particular the construction industry, to the core export sector. Third, linking establishment-level data with administrative data on employees, I could demonstrate how through rent sharing at the firm and industry level this shift translated into increased wage inequality. Against the backdrop of these findings, the German government's opposition against exchange rate revaluations can be seen as an instance of politics for markets (Iversen and Soskice, 2015) wherein the state sides with the capital-intensive, core manufacturing sector, reinforcing dualization and Germany's export-led growth model at once.

Whereas universalist economic explanations that point to the importance of technological change and global trade offer sweeping answers for rising labor market inequality, any institutional account of growing inequality must be constructed in a more piecemeal fashion since institutions are as country-specific as the trajectories of their change. Drawing on the political economy of exchange rate regimes, this study adds a new piece to this endeavor and 
broadens the scope beyond domestic developments such as deunionization, changes in the minimum wage, managerial rent, occupational closure, or the fragmentation of collective bargaining. However, the focus on the EMU should not be mistaken for an attempt to downplay the importance of these established factors. In addition, I concentrated on differences between industries here due to the focus on industry rents. Future research could depart from this simplification and explore between-firm heterogeneity regarding both the effect of the EMU on corporate profits and the process of rent sharing (Kristal, 2017).

I showed that the EMU has contributed to shape the peculiar pattern by which wage inequality has risen in Germany, and that puzzles sociologists, economists, and political scientists alike. My finding that the EMU has increased inequality, however, does not rule out that the EMU may nevertheless represent a Pareto improvement, nor does it refute the claim that in absolute terms everyone in the German economy suffered a disadvantage from the EMU. By controlling for GDP growth in the analysis, I deliberately chose to take an agnostic position on whether the overall effect of the EMU on German national income was positive, negative, or neutral. The identification of winners and losers in absolute terms thus awaits the conclusion of the current controversy over this question in economics that necessarily complements this analysis.

Having said that, my findings caution against extrapolating to Germany's general interest from the interest of its manufacturing industry - empirically the clear positive outlier among all industries. Although such extrapolations are ubiquitous, and not just in the German public debate, they bias the discussion and thus impede a more sober deliberation over the future of the Euro.

\section{Literature}

Abell, P. (2001). Causality and Low-Frequency Complex Events. The Role of Comparative Narratives. Sociological Methods \& Research, 30, 57-80.

Allison, P. (2009). Fixed Effects Regression Models. Thousand Oaks: Sage.

Antonczyk, D., DeLeire, T., \& Fitzenberger, B. (2012). Polarization and Rising Wage Inequality: Comparing the U.S. and Germany. ZEW Discussion Paper 10-015.

Autor, D. (2015). Why Are There Still So Many Jobs? The History and Future of Workplace Automation. Journal of Economic Perspectives, 29, 3-30.

Autor, D., Katz, L., \& Kearney, M. (2008). Trends in U.S. Wage Inequality: Revising the Revisionists. The Review of Economics and Statistics, 90, 300-323.

Baccaro, L., \& Benassi, C. (2017). Throwing out the ballast: growth models and the liberalization of German industrial relations. Socio-Economic Review, 15, 85-115.

Baccaro, L., \& Pontusson, J. (2016). Rethinking Comparative Political Economy: The Growth Model Perspective. Politics \& Society, 44, 175-207.

Baumgarten, D. (2013). Exporters and the rise in wage inequality: Evidence from German linked employer-employee data. Journal of International Economics, 90, 201-217. 
Bivens, J., \& Mishel, L. (2013). The Pay of Corporate Executives and Financial Professionals as Evidence of Rents in Top 1 Percent Incomes. Journal of Economic Perspectives, 27, 57-78.

Broz, J., \& Frieden, J. (2001). The Political Economy of International Monetary Relations. Annual Review of Political Science, 4, 317-343.

Card, D., Heining, J., \& Kline, P. (2013). Workplace Heterogeneity and the Rise of West German Wage Inequality. The Quarterly Journal of Economics, 128, 967-1015.

Card, D., Cardoso, A., Heining, J., \& Kline, P. (2016). Firms and Labor Market Inequality: Evidence and Some Theory. eml.berkeley.edu/ pkline/papers/cchk-march14.pdf

Carlin, W., \& Soskice, D. (2009). German economic performance: disentangling the role of supply-side reforms, macroeconomic policy and coordinated economy institutions. Socio-Economic Review, 7, 67-99.

Carruthers, B., \& Babb, S. (1996). The Color of Money and the Nature of Value: Greenbacks and Gold in Postbellum America. American Journal of Sociology, 101, 1556-1591.

Cesaratto, S., \& Stirati, A. (2011). Germany and the European and Global Crises. International Journal of Political Economy, 39, 56-86.

Correia, S. (2015). reghdfe: Stata module to perform linear or instrumental-variable regression absorbing any number of high-dimensional fixed effects. Statistical Software Components. Boston College Department of Economics. https://ideas.repec.org/c/boc/bocode/s457874.html

Dauth, W., Findeisen, S., \& Suedekum, J. (2014). The rise of the East and the Far East: German labor markets and trade integration. Journal of the European Economic Association, 12, 1643-1675.

Dauth, W., Schmerer, H.-J., \& Winkler, E. (2015). Exporters and wage inequality during the Great Recession: Evidence from Germany. Economics Letters, 136, 137-140.

DiPrete, T., Goux, D., Maurin, E., \& Quesnel-Vallee, A. (2006). Work and pay in flexible and regulated labor markets: A generalized perspective on institutional evolution and inequality trends in Europe and the U.S. Research in Social Stratification and Mobility, 24, 311-332.

Dustmann, C., Fitzenberger, B., Schönberg, U., \& Spitz-Oener, A. (2014). From Sick Man of Europe to Economic Superstar: Germany's Resurgent Economy. Journal of Economic Perspectives, 28, 167 188.

Dustmann, C., Ludsteck, J., \& Schönberg, U. (2009). Revisiting the German Wage Structure. The Quarterly Journal of Economics, 124, 843-881.

Eichengreen, B., \& Frieden, J. (1993). The political economy of European monetary unification: an analytical introduction. Economics and Politics, 5, 85-104.

Elwert, F., \& Winship, C. (2014). Endogeneous Selection Bias: The Problem of Conditioning on a Collider Variable. Annual Review of Sociology, 40, 31-53.

Feenstra, R., \& Hanson, G. (1999). The Impact of Outsourcing and High-Technology Capital on Wages: Estimates for the United States, 1979-1990. The Quarterly Journal of Economics, 114, 907-940.

Fernández-Villaverde, J., Garicano, L., \& Santos, T. (2013). Political Credit Cycles: The Case of the Eurozone. Journal of Economic Perspectives, 27, 145-166.

Fischer, G., Janik, F., Müller, D., \& Schmucker, A. (2009). The IAB Establishment Panel: Things Users Should Know. Schmollers Jahrbuch, 129, 133-148.

Fitzenberger, B., Osikominu, A., \& Völter, R. (2006). Imputation Rules to Improve the Education Variable in the IAB Employment Subsample. Schmollers Jahrbuch, 126, 405-436.

Frieden, J. (1994). Exchange Rate Politics: Contemporary Lessons from American History. Review of International Political Economy, 1, 81-103.

Frieden, J. (2015). Currency Politics. The Political Economy of Exchange Rate Policy. Princeton: PUP.

Frieden, J., \& Walter, S. (2017). Understanding the Political Economy of the Eurozone Crisis. Annual Review of Political Science, 20, 371-390.

Gangl, M. (2010). Causal inference in sociological research. Annual Review of Sociology, 36, 21-47.

Gelman, A., \& Imbens, G. (2013). Why ask Why? Forward Causal Inference and Reverse Causation. NBER Working Paper 19614. 
Hall, P. (2012). The Economics and Politics of the Euro Crisis. German Politics, 21, 355-371.

Hancké, B. (2013). Unions, Central Banks, and EMU. Labour Market Institutions and Monetary Integration in Europe. Oxford: OUP.

Hancké, B., \& Rhodes, M. (2005). EMU and Labor Market Institutions in Europe. The Rise and Fall of National Social Pacts. Work and Occupations, 32, 196-228.

Hassel, A. (2014). The Paradox of Liberalization. Understanding Dualism and the Recovery of the German Political Economy. British Journal of Industrial Relations, 52, 57-81.

Heining, J., Klosterhuber, W., \& Seth, S. (2014). An Overview on the Linked Employer-Employee Data of the Institute of Employment Research (IAB). Schmollers Jahrbuch, 134, 141-148.

Henning, C. (1994). Currencies and Politics in the United States, Germany, and Japan. Washington, D.C.: Institute for International Economics.

Höpner, M., \& Lutter, M. (2017). The diversity of wage regimes: Why the Eurozone is too heterogeneous for the Euro. European Political Science Review. doi:10.1017/S1755773916000217

Höpner, M., \& Spielau, A. (2016). Besser als der Euro? Das Europäische Währungssystem, 1979-1998. Berliner Journal für Soziologie, 26, 273-296.

IG Metall (2011). Schuldenkrise in der Euro-Zone: 10 Gründe für den Euro und die Währungsunion. Accessed at https://www.igmetall.de/schuldenkrise-in-der-euro-zone-8301.htm on March 30, 2016.

Iversen, T., \& Soskice, D. (2015). Politics for markets. Journal of European Social Policy, 25, 76-93.

Johnston, A. (2012). European Economic and Monetary Union's perverse effects on sectoral wage inflation: Negative feedback effects from institutional change? European Union Politics, 13, 345-366.

Johnston, A., \& Regan, A. (2016). European Monetary Integration and the Incompatibility of National Varieties of Capitalism. Journal of Common Market Studies, 54, 318-336.

Katz, L., Summers, L., Hall, R., Schultze, C., \& Topel, R. (1989). Industry Rents: Evidence and Implications. Brookings Papers on Economic Activity. Microeconomics, 209-290.

Kupilas, B. (2013, April 29). Interview with Dr. Rainer Dulger. Handelsblatt, Düsseldorf.

Koselleck, R., Gschnitzer, F., Werner, K., \& Schönemann, B. (1992). Volk, Nation, Nationalismus, Masse. In R. Koselleck, W. Conze \& O. Brunner (Eds.), Geschichtliche Grundbegriffe. Historisches Lexikon zur politisch-sozialen Sprache in Deutschland (Vol. 7, pp. 141-431). Stuttgart: Klett-Cotta.

Kristal, T. (2017). Who Gets and Who Gives Employer-Provided Benefits? Evidence from Matched Employer-Employee Data. Social Forces, doi:10.1093/sf/sox048.

Kristal, T., \& Cohen, Y. (2017). The causes of rising wage inequality: the race between institutions and technology. Socio-Economic Review, 187-212.

Lane, P. (2012). The European Sovereign Debt Crisis. Journal of Economic Perspectives, 26, 49-68.

Lin, K.-H. (2015). The Financial Premium in the US Labor Market: A Distributional Analysis. Social Forces, 94, 1-30.

Mahoney, J. (2012). The Logic of Process Tracing Tests in the Social Sciences. Sociological Methods \& Research, 41, 570-597.

Merkel, A. (2011). Rede der Bundeskanzlerin anlässlich des Deutschen Handwerkstages, Berlin, 16.09.2011.

Morgan, S., \& Winship, C. (2007). Counterfactuals and Causal Inference. Methods and Principles for Social Research. Cambridge: CUP.

Nölke, A. (2016). Economic causes of the Eurozone crisis: the analytical contribution of Comparative Capitalism. Socio-Economic Review, 14, 141-161.

Ochsenfeld, F. (2017) 'Replication Data for: Mercantilist Dualization: The Introduction of the Euro, Redistribution of Industry Rents, and Wage Inequality in Germany, 1993-2008', doi:10.7910/DVN/3CBOAT, Harvard Dataverse, V1.

Oesch, D. (2013). Occupational Change in Europe. How Technology and Education Transform the Job Structure. Oxford: OUP. 
Ó Riain, S. (2014). The Rise and Fall of Ireland's Celtic Tiger. Liberalism, Boom and Bust. Cambridge: CUP.

Palier, B., \& Thelen, K. (2010). Institutionalizing Dualism. Complementarities and Change in France and Germany. Politics \& Society, 38, 119-148.

Philippon, T., \& Reshef, A. (2012). Wages and Human Capital in the U.S. Finance Industry: 1909-2006. The Quarterly Journal of Economics, 127, 1551-1609.

Piketty, T., \& Saez, E. (2003). Income Inequality in the United States, 1913-1998. The Quarterly Journal of Economics, 118, 1-39.

Pisani-Ferry, J. (2014). The Euro Crisis and Its Aftermath. Oxford: OUP.

Quaglia, L., \& Royo, S. (2015). Banks and the political economy of the sovereign debt crisis in Italy and Spain. Review of International Political Economy, 22, 485-507.

Rajan, R. (2010). Fault Lines: How Hidden Fractures Still Threaten the World Economy. Princeton: PUP.

Scharpf, F. (2011). Monetary Union, Fiscal Crisis and the Pre-emption of Democracy. Journal for Comparative Government and European Policy, 9, 163-198.

Scharpf, F. (2015). Is There a Successful 'German Model'? In B. Unger (Ed.), The German Model - Seen by its Neighbours (pp. 87-103). Leipzig: SE Publishing.

Sinn, H.-W. (2012). Die Target-Falle: Gefahren für unser Geld und unsere Kinder. München: Hanser.

Sinn, H.-W., \& Wollmershäuser, T. (2012). Target-Salden und die deutsche Kapitalbilanz im Zeichen der europäischen Zahlungsbilanzkrise. Ifo Working Paper, 149.

Sørensen, A. (2000). Toward a Sounder Basis for Class Analysis. American Journal of Sociology, 105, 1523-1558.

Streeck, W. (1991). On the Institutional Conditions of Diversified Quality Production. In E. Matzner \& W. Streeck (Eds.), Beyond Keynesianism. The Socio-Economics of Production and Employment (pp. 21-61). London: Edward Elgar.

Streeck, W. (2009). Re-Forming Capitalism. Institutional Change in the German Political Economy. Oxford: OUP.

Streeck, W. (2013). Gekaufte Zeit. Die vertagte Krise des demokratischen Kapitalismus. Berlin: Suhrkamp.

Streeck, W. (2014). Small-State Nostalgia? The Currency Union, Germany, and Europe: A Reply to Jürgen Habermas. Constellations, 21, 213-221.

Thelen, K. (2004). How Institutions Evolve. The Political Economy of Skills in Germany, Britain, the United States, and Japan. Cambridge: CUP.

Thelen, K. (2014). Varieties of Liberalization and the New Politics of Social Solidarity. Cambridge: CUP.

Thelen, K., \& Busemeyer, M. (2012). Institutional Change in German Vocational Training: From Collectivism towards Segmentalism. In M. Busemeyer \& C. Trampusch (Eds.), The Comparative Political Economy of Collective Skill Systems (pp. 68-100). Oxford: OUP.

Tomaskovic-Devey, D., \& Lin, K.-H. (2011). Income Dynamics, Economic Rents, and the Financialization of the U.S. Economy. American Sociological Review, 76, 538-559.

Weeden, K., \& Grusky, D. (2014). Inequality and Market Failure. American Behavioral Scientist, 58, 473-491.

Ziefle, A., \& Gangl, M. (2014). Do Women Respond to Changes in Family Policy? A Quasi-Experimental Study of the Duration of Mothers' Employment Interruptions in Germany. European Sociological Review, 30, 562-581. 


\section{Appendix}

Figure A1. Distribution of employees across decile bins of the overall wage distribution by seven industries, for 2004.
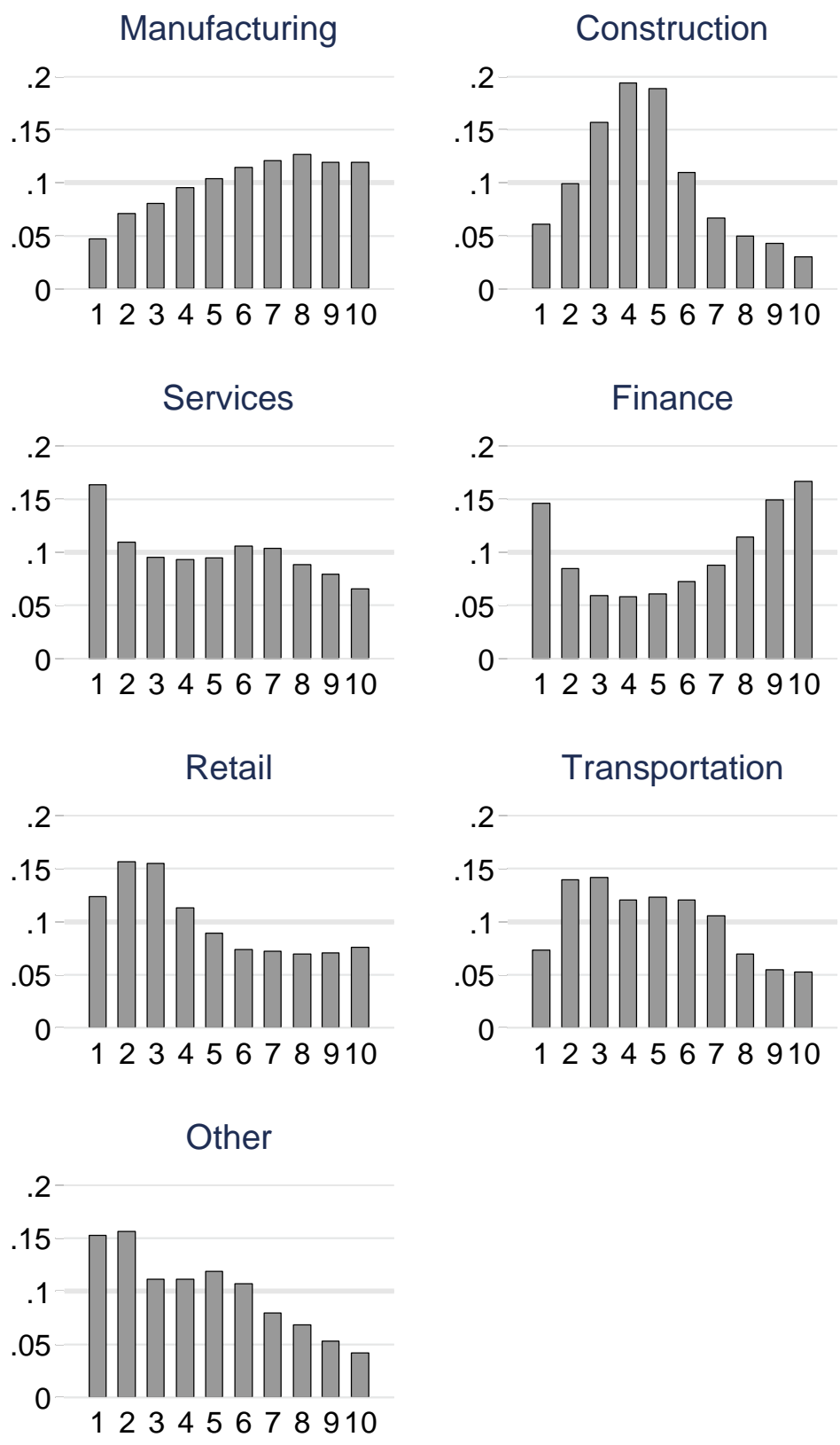

Note: Horizontal axis: relative frequency, vertical axis: decile bin, lowest (1) to highest (10). Western Germany, full-time, social insurance covered employees, age 20-60; 'Other' is Agriculture, Mining, and Utilities. Source: SIAB, own calculation. 
Table A1. Industry-specific within-establishment effects of the real interest rate difference between Germany and Spain/Ireland on profits.

$$
\text { Coef. s.e. }
$$

Real interest rate Germany real interest rate Spain//reland (annually, in percentage points;

$\begin{array}{llll}\text { reference: services) } & -.025 * & & (.0119) \\ \times \text { Manufacturing } & .061 & * & (.0173) \\ \times \text { Construction } & -.034 & & (.0270) \\ \times \text { Finance } & -.012 & & (.0185) \\ \times \text { Retail } & -.017 & & (.0237) \\ \times \text { Transportation } & .002 & & (.0204) \\ \times \text { Other } & .002 & & (.0237)\end{array}$

Annual growth in trade of

Sweden and Switzerland with Eastern Europe and China (in percentage points; reference:

$\begin{array}{lrrr}\text { services) } & .0010 & & (.0028) \\ \times \text { Manufacturing } & -.003 & & (.0034) \\ \times \text { Construction } & .008 & & (.0056) \\ \quad \times \text { Finance } & -.001 & & (.0037) \\ \quad \times \text { Retail } & -.001 & & (.0035) \\ \quad \times \text { Transportation } & -.004 & & (.0037) \\ \quad \times \text { Other } & -.008 & & (.0045) \\ \text { Annual GDP growth } & .071{ }^{* *} & (.0254) \\ \text { Annual GDP growth, squared } & .0048 & & (.00802) \\ \text { Establishment fixed-effects } & \text { Yes } & & \\ \mathrm{N}= & 62,237 & & \end{array}$

Notes: $\quad{ }^{*} \mathrm{p}<.05, \quad{ }^{* *} \mathrm{p}<.01, \quad{ }^{* *} \mathrm{p}<.001 ; \quad$ Profit situation: 0 =insufficient $1=$ (just) sufficient $2=$ satisfactory $3=$ good 4=very good. Errors clustered in 112 industry-years.

Source: IAB Establishment Panel, Western Germany, 19932008, IMF IFS, UN Comtrade. 
Table A2. Rent-sharing: effects of changes in corporate profits on real wages, estimates from a distributed-lag three-way fixed-effects regression.

\begin{tabular}{|c|c|c|c|}
\hline & Coef. & & s.e. \\
\hline \multicolumn{4}{|l|}{ Establishment-level profits } \\
\hline unlagged & .005 & $* *$ & $(.0007)$ \\
\hline one-year lag & .005 & $* *$ & $(.0006)$ \\
\hline \multicolumn{4}{|l|}{ Industry-level profits } \\
\hline unlagged & .018 & & $(.0091)$ \\
\hline one-year-lag & .014 & & $(.0073)$ \\
\hline two-year-lag & .020 & & $(.0075)$ \\
\hline Establishment fixed-effects & \multicolumn{3}{|c|}{ Yes } \\
\hline Year fixed-effects & \multicolumn{3}{|c|}{ Yes } \\
\hline Occupation-by-period fixed-effects & \multicolumn{3}{|c|}{ Yes } \\
\hline \multicolumn{4}{|l|}{ Person controls } \\
\hline \multicolumn{4}{|l|}{$\begin{array}{l}\text { Worker type } \\
\text { (ref.: unskilled blue collar) }\end{array}$} \\
\hline Skilled blue collar & .081 & ** & $(.0039)$ \\
\hline White collar & .197 & ** & $(.0076)$ \\
\hline Foreigner & -.020 & ** & $(.0038)$ \\
\hline Female & -.052 & ** & $(.0129)$ \\
\hline $\begin{array}{l}\text { Experience, years (ref.:voc. training and } \\
\text { Abitur) }\end{array}$ & .0720 & $* *$ & $(.00332)$ \\
\hline$\times$ Female & -.0165 & ** & $(.00210)$ \\
\hline$\times$ No vocational training & -.0266 & $* *$ & $(.00396)$ \\
\hline$\times$ Vocational training, no Abitur & -.0331 & ** & $(.00331)$ \\
\hline$\times$ College & -.0144 & * & $(.00409)$ \\
\hline $\begin{array}{l}\text { Experience, years, squared (ref.:voc. } \\
\text { training and Abitur) }\end{array}$ & -.00283 & ** & $(.000243)$ \\
\hline$\times$ Female & .00028 & * & $(.000103)$ \\
\hline$\times$ No vocational training & 00145 & ** & $(.000262)$ \\
\hline$\times$ Vocational training, no Abitur & 00165 & ** & $(.000244)$ \\
\hline$\times$ College & 00097 & * & $(.000293)$ \\
\hline Experience, years, cubed (ref.:College) & .00002 & ** & $(.000004)$ \\
\hline$\times$ Female & .00000 & & $(.000002)$ \\
\hline$\times$ No vocational training & -.00001 & & $(.000004)$ \\
\hline$\times$ Vocational training, no Abitur & -.00001 & & $(.000004)$ \\
\hline$\times$ Vocational training and Abitur & .00002 & * & $(.000006)$ \\
\hline \multicolumn{4}{|l|}{ Education (ref.: no vocational training) } \\
\hline Vocational training, no Abitur & .102 & ** & $(.0207)$ \\
\hline$\times 1997-2000$ & -.001 & & $(.0055)$ \\
\hline$\times 2001-2004$ & -.005 & & $(.0060)$ \\
\hline$\times 2005-2008$ & -.009 & & $(.0064)$ \\
\hline Vocational training and Abitur & -.064 & & $(.0219)$ \\
\hline$\times 1997-2000$ & -.002 & & $(.0087)$ \\
\hline$\times 2001-2004$ & -.007 & & $(.0100)$ \\
\hline$\times 2005-2008$ & -.016 & & $(.0238)$ \\
\hline College degree & .167 & ** & $(.0133)$ \\
\hline$\times 1997-2000$ & -.007 & & $(.0062)$ \\
\hline$\times 2001-2004$ & -.009 & & $(.0116)$ \\
\hline$\times 2005-2008$ & -.013 & & $(.0104)$ \\
\hline $\mathrm{N}=$ & \multicolumn{3}{|c|}{$9,669,681$} \\
\hline
\end{tabular}

Notes: ${ }^{\star} \mathrm{p}<.05,{ }^{* \star} \mathrm{p}<.01,{ }^{\star * \star} \mathrm{p}<.001$; Errors clustered in 98 industry-years and 11,524 establishments. Source: LIAB 1995-2008; Western Germany; full-time, social insurance covered, private sector employees, age 20-60. 